Phung Thanh Quang

National Economics University (Vietnam)

Khuc The Anh

National Economics University (Vietnam)

\title{
Demographic Factors Affecting the Level of Financial Literacy in Rural Areas: The Case of Vietnam
}

\begin{abstract}
This article measures the level of financial literacy in the rural areas of Vietnam. The financial literacy is usually concerned by financial institutions and government organizations. This is considered to be an indicator that contributes to the assessment of the quality and potential growth of the financial system. In the article the determinants of financial literacy in Vietnam are identified. In result the authors propose a designed financial literacy enhancement programme for implementation.
\end{abstract}

Keywords: demography, financial literacy, rural areas, Vietnam

\section{Introduction}

Vietnam is an emerging economy with high level of economic growth and integration. However, the financial system of Vietnam still lags behind many other countries in terms of size, service diversification and professionalism (Tran et al., 2017). Thus, the demand for skilled workforce with in-depth knowledge for financial intermediary system has become crucial. Such human resource has substantial effects not only on sustainable development of banking and financial system but also the whole economy. To measure and evaluate its affect on financial system, researchers come up with the term "financial literacy" which applies not only to people who are professionally trained in financial field but also the residents who are more and more involved in financial activities.

In some countries, such as Singapore, high level of financial inclusion partly indicates the residents' high perception of financial issues, but in Vietnam the level of financial inclusion is still low (WB, 2015). Nielson (2010) pointed out that the lack of clear understanding of 
products and services is the main reason for the fact that a lot of Vietnamese residents avoid using credit cards and insurance services. This fact shows an obvious relationship between Vietnamese residents' low financial literacy and their difficulty in approaching modern financial services and instruments, which is an obstacle for the development of modern banking and financial services in Vietnam.

In fact, there is still no in-depth research in Vietnam about financial literacy. Previous studies only provided assessment of how expertise of financial staff affected the quality of financial activities, without taking into account other subjects who were also involved in financial activities. Financial literacy usually refers to evaluation of knowledge about how to approach and use financial services in general and in practice rather than professional knowledge. Financial education in Vietnam, which is usually judged based on diploma and certificates, does not really show individuals' skills of making investment and using money efficiently in a realistic market. Even a financially well-educated individual still may have low level of financial literacy. Therefore, measurement of financial literacy is a really emergent task, which contributes to finding appropriate direction and adjustment to meet the requirement of financial system, and also to help financial policy makers to be aware of the residents' financial perception in order to provide necessary solutions.

In addition, currently, financial literacy measurements have still been conducted based on the reviews of the OECD countries, which do not fit the context of a transitional economy such as Vietnam. More remarkably, some of the previous researches about financial literacy mostly focused on urban areas, or people working in the financial institutions or students (Ngo, Le, 2016; Tran, 2017; Nguyen, 2015; Marszałek-Kawa, 2012), while excluding rural areas due to many problems such as (1) the inhabitants of the rural areas in the North and the Central Vietnam usually save a significant amount of their income for future needs while people in the remaining areas - typically Southern area - usually spend most of their income, primarily leads to low financial accumulation and difficulties in business development through personal financial autonomy; (2) the volume of savings in rural areas - although it has increased along with the average income of Vietnamese - yet still very small, therefore, the use of these savings also has become a problem since they are not big enough to make small purchases which may be not small to many households. The "treatment" to the earnings and savings of rural people, especially poor people - is becoming a big issue.

However, if measurement of financial literacy in rural areas can be conducted based on different criteria - to make policy implications for the management agencies, the understanding of human factors affecting the results is also a matter of concern, because those factors would help identify the cause of the low financial literacy level in Vietnam (ranked 90/118) (WB, 2015): only $24 \%$ of adults in Vietnam had average financial literacy in comparison with developed countries whereas the rest - mainly in rural areas, had very limited knowledge, including financial knowledge, attitude and behaviors. This is one of the reasons for the low income status in some regions of Vietnam mentioned in some previous researches. Therefore, 
this article will initially survey demographic factors that affect the financial literacy level of inhabitants in rural areas, then to measure and provide specific results.

\section{Literature review}

There have been a lot of researches on financial literacy mentioned in the studies of foreign authors, especially in the developed countries that have developed financial systems and people can access financial services easily, the concept of "financial literacy" is usually concerned by financial institutions and government organizations. This is considered to be an indicator that contributes to the assessment of the quality and potential growth of the financial system.

\section{Some Concepts of Financial Literacy}

In spite of the expansion of research on financial literacy over time, there has been very little consistency in defining the concept as different authors might use it with different meaning and implications (Hung et al, 2009). Furthermore, the study underlined the ambiguity in the use of financial literacy, especially in the difference between the definitions of financial literacy or financial education. Robb et al (2012) distinguished the definition, claiming that financial literacy related to the ability to understand financial information and make decisions efficiently by using such information, while financial education means that people just need to memorize a set of facts. In summary, the main focus of financial education is knowledge, while financial literacy related to not only knowledge but also financial attitude and behavior. Therefore, as McCormeck (2009) and Huston (2010) claimed, financial literacy is beyond the major concept of financial education. The comprehensive concepts of financial literacy collected in the following table:

Table 1. The major concepts and related aspects of financial literacy

\begin{tabular}{lll}
\hline Definition & Mentioned dimensions & Author \\
\hline $\begin{array}{l}\text { Financial knowledge and application of those knowl- } \\
\text { edge with self-confidence to make financial decisions }\end{array}$ & $\begin{array}{l}\text { Financial knowledge and its } \\
\text { application }\end{array}$ & Huston (2010) \\
\hline $\begin{array}{l}\text { The ability to make efficient assessment in terms of } \\
\text { financial usage and management }\end{array}$ & $\begin{array}{l}\text { Decisions on money usage } \\
\text { and management }\end{array}$ & Noctor et al. (1992) \\
\hline $\begin{array}{l}\text { The ability to use acquired knowledge and skills to } \\
\text { have better administration }\end{array}$ & $\begin{array}{l}\text { Financial knowledge and } \\
\text { skills }\end{array}$ & Hung et al. (2009) \\
\hline $\begin{array}{l}\text { The ability to interpret financial information and } \\
\text { make efficient decisions by using such information }\end{array}$ & $\begin{array}{l}\text { Understanding and decision } \\
\text { making }\end{array}$ & Robb et al. (2012) \\
\hline $\begin{array}{l}\text { A concept that goes beyond financial education, as } \\
\text { the affecting of financial knowledge on behaviors is } \\
\text { affected by financial attitude }\end{array}$ & $\begin{array}{l}\text { Knowledge, behavior and } \\
\text { attitude }\end{array}$ & $\begin{array}{l}\text { Norvilitis and } \\
\text { MacLean (2010) }\end{array}$ \\
\hline $\begin{array}{l}\text { Selection among alternatives to attain financial } \\
\text { efficiency }\end{array}$ & Efficient choice & Criddle (2006) \\
\hline
\end{tabular}




\begin{tabular}{lll}
\hline Definition & Mentioned dimensions & Author \\
\hline Making well informed financial decisions & Financial choice & Remund (2010) \\
\hline $\begin{array}{l}\text { The special capital resource of humans, measured by } \\
\text { the issues related to finance. }\end{array}$ & Financial knowledge & $\begin{array}{l}\text { Robb and Sharpe } \\
(2009)\end{array}$ \\
\hline $\begin{array}{l}\text { Measured by the questionnaires related to fundamen- } \\
\text { tal financial concepts, such as interest rate, inflation } \\
\text { and risk diversification }\end{array}$ & Financial knowledge & $\begin{array}{l}\text { Lusardi and Mitch- } \\
\text { ell (2014) }\end{array}$ \\
\hline $\begin{array}{l}\text { Financial literacy includes: financial knowledge, } \\
\text { financial behaviors and financial attitude }\end{array}$ & $\begin{array}{l}\text { Financial knowledge, finan- } \\
\text { cial behaviors and financial } \\
\text { attitude }\end{array}$ & $\begin{array}{l}\text { Atkinson and } \\
\text { Messy (2012); } \\
\text { OECD (2013) }\end{array}$ \\
\hline
\end{tabular}

Source: Prepared by authors

Based on these studies, it can be said that financial literacy must include all of 3 factors that are financial knowledge, financial attitude and financial behaviors. This also is the basis that helped the authors conduct the survey in the following part.

\section{Reflective Factors of Financial Literacy}

\section{Financial Knowledge}

In this research financial knowledge is defined as the awareness understanding of the financial concepts and procedures as well as the use of this understanding to solve financial problems (IGI, 2017).

Knowledge is the most apparent factor mentioned in all different definitions of financial literacy as well as an important factor needed to improve a personal financial status. The importance of financial knowledge is measured in researches of Vitt et al. (2000) and Braunstein \& Welch (2002). Many researchers, analysts and policy makers consider the lack of financial knowledge as one of the main reason leading to low financial literacy (Collins, 2012; Huston, 2010; Nicolini et al., 2013). Zhan et al. (2006) analyzed and pointed out that enhancing financial knowledge can improve financial literacy (see also Taft et al. (2013), Scheresberg (2013)).

\section{Hypothesis 1 (H1): Financial knowledge (KT) is a financial literacy's (DTTC) reflective factor.}

\section{Financial Attitude}

Attitude is a factor that drives an individual's demeanor and state of mind in making decisions during transactions (Moore, 2003). In another way, financial attitude refers to one's beliefs and values related to various personal finance concepts, such as whether one believes it is important to save money (Chowa et al., 2012). These definitions are supported by researchers and analysts by defining financial attitude as the way a person think and feel about finance, directly influencing their behaviors (Kaufman, 2017). 
Atkinson \& Messy (2012) point out that attitude is a very important factor reflecting financial literacy. Financial attitude is put into financial literacy regression as an independent variable in many researches, such as Godwin \& Carroll (1986), Godwin \& Koonce (1992), Godwin (1994). Concretely, Godwin (1994) measured the influence of this variable to personal financial management and come to conclusion that financial attitude is a crucial factor to predict cash flow of an individual. People with positive financial attitude tend to manage money better (see also Atkinson \& Messy, 2012; OECD, 2013).

Hypothesis 2 (H2): Financial attitude (HV) is a financial literacy's reflective factor.

\section{Financial Behavior}

Financial behavior is a term mentioned by many researches in recent years, especially in behavioral economics. Researchers have considered and intensively analyzed this definition, e.g. Muske \& Winter (2001), Hogarth et al. (2002), Hilgert et al. (2003), O'Neill \& Xiao (2004), Xiao (2016). Financial behavior is referred to as any human behavior that is relevant to money management (Xiao, 2004). Developing from this, Tezel (2015) points out that financial behavior is the capability to have the knowledge about the overall impact of financial decision in any circumstances of a person and make correct decisions relating to cash management, risk prevention and fund planning. This explanation is used in this research as the definition of financial behavior.

Atkinson \& Messy (2012) and OECD (2013) - all support the claim that financial behavior can reflect financial literacy. The more positive financial behavior, the higher financial literacy. Moreover, Hilgert et al. (2003) and Taft et al. (2013) prove that this relationship has statistical meaning (see also Robb \& Wodyard, 2011).

Hypothesis 3 (H3): Financial behavior (TD) is a financial literacy's reflective factor.

\section{Determinants of Financial Literacy}

\section{Income}

Lusardi \& Tufano (2009) indicate that people with higher income often have better financial literacy scores. This result is supported by Clercq et al. (2009), Potrich et al. (2015), và Sekar \& Gowri (2015), Lusardi \& Mitchell (2011), Atkinson \& Messy (2012).

Hypothesis 4 (H4): There is a significant relationship between respondent's income and financial literacy. 


\section{Education Level}

Within the framework of the International Standard Classification of Education (ISCED, 2011), levels of education are an ordered set of categories, intended to group educational programmes in relation to gradations of learning experiences and the knowledge, skills and competencies which each programme is designed to impart. Levels of education are therefore a construct based on the assumption that education programmes can be grouped into an ordered series of categories. These categories represent broad steps of educational progression in terms of the complexity of educational content. The education level of an individual is the most advanced programme his/her has joined in national education system. Friedman (2005) has observed in his research that educational barriers may discourage some respondents from taking positive action to manage their finances. Similarly, Lusardi \& Mitchell (2013) have provided practical evidence that people with bachelor degrees will score five time higher in financial literacy questionnaire than people who have just finished high school.

Hypothesis 5 (H5): There is a significant positive relationship between respondent's education and financial literacy.

Age

Lusardi \& Mitchell (2007) affirm that financial behavior, especially planning and budgeting, is different between young people and the middle-aged. However, Scheresberg (2013) states that this difference is very light and not significant. So, the relationship between age and financial literacy score is diversified among researchers.

Hypothesis 6 (H6): There is a significant positive relationship between respondent's age and financial literacy.

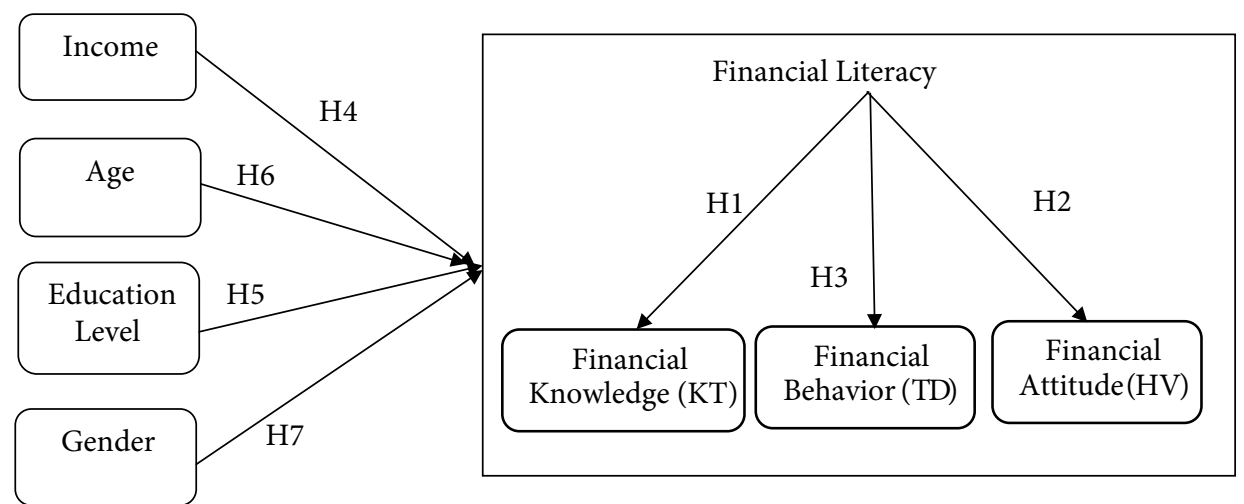

Figure 1. Research model 


\section{Gender}

Chen \& Volpe (1998), Banks \& Oldfield (2007), Lusardi (2008), Lusardi \& Tufano (2009) and Scheresberg (2013) are unanimous in the opinion that female is less confident about financial knowledge than male. But, some researchers claimed that this gap is very slight (Bucher et al., 2011; Bhushan \& Medury, 2013; Nanzir \& Leibbrandt, 2018). Conclusively, gender is a determinant influencing financial literacy.

Hypothesis 7 (H7): There is a significant relationship between respondent's gender and financial literacy.

\section{The survey of the factors that affecting the level of financial literacy in rural area of Vietnam}

\section{Qualitative research}

A qualitative research was conducted through in-depth interviews with experts in the field of personal finance, micro-finance, education and quantification to provide the most accurate and selective measure of the impact of financial literacy in rural areas of Vietnam, as well as adjustments to the survey questionnaire with people living in rural areas of Vietnam. In-depth interviews were conducted with 12 experts ( 3 in the financial sector, 3 in the field of personal finance, 2 in the field of micro-finance, 1 in the field of public finance, 1 in the field of education and 2 people in the quantitative field). Each interview lasts from 25 to 40 minutes.

Qualitative results after the in-depth interviews with experts generally support the proposed model of the authors. Specifically: (1) financial literacy is accurately measured through three reflecting factors are financial knowledge, financial attitude and financial behaviour. In particular, financial behaviour is a factor that is considered to have the highest reflective weight to an individual's financial literacy; (2) Determinants affecting financial literacy are: age, gender, education level and income; (3) financial literacy impacts positively on income.

\section{Questionnaire and data analysis}

\section{Questionnaire}

In this research, the authors use concepts: financial literacy, financial knowledge, financial attitude, financial behaviour. All of these scales were built on the basis of previous studies, especially OECD (2018) and adapted to the Vietnamese along with qualitative research. The scale is built in Likert 5 levels, of which 1 is completely disagree, 5 is completely agree.

Specifically, the scale of financial knowledge includes 7 observed variables, the scale of financial attitudes includes 5 observed variables and the scale of financial behaviour 
includes 9 observed variables. After the preliminary quantitative research, an observable variable was excluded from the model because it was not statistically significant. Thus, the official scale includes: 6 observable variables for the scale of financial knowledge, 5 observed variables for the financial attitude scale and 9 observed variables for the scale of financial behaviour. After that, the financial literacy score was calculated by averaging the scores of the above scales.

The survey tool was built based on the conceptual variables observed in the model. In addition, the survey has demographic questions such as gender, age, education attainment, employment and income. The questions in the questionnaire were reconciled by the authors to check the semantics between the original English and the Vietnamese translation.

\section{Sample}

The sample was randomly taken from many rural areas in different provinces across the country. The total number of analyzed observations was 512, including 197 males (38.5\%) and 315 females $(61.5 \%)$. The age of the respondents was from 18 to 70 years, and the group of people aged 26-40 accounted for the highest proportion (42\%). Through the statistics of the survey sample, we can see that, the financial literacy scores are classified according to gender, age, education and income groups.

\section{Results}

\section{The Impact of Internal Factors on Financial Literacy}

The results of factor analysis show that the coefficient $\mathrm{KMO}=0.806>0.5$, factor analysis is appropriate. The results of the first factor analysis with three components were theoretically defined with the Varimax rotation, which results in four component factors. The variables that measure the "Financial Knowledge" factor do not converge into a total factor but are divided into two components. When reviewing the meaning of the indicators of "Financial Knowledge", the author accepted the observed variables of this factor were split into two components of theoretical significance. The results of factor analysis show that the research model will have to be changed.

The research model will now be the "Financial literacy" factor that will be reflected directly by four components: (1) Financial behavior (9 items), (2) Financial attitude (5 items), (3) Financial knowledge related to interest rates and inflation (4 items) and (4) Financial knowledge related to investment and risk ( 2 items). Indicators have "factor loading" $>0.5$; This indicates that the observed variables have the value, relevance, statistical significance in factor analysis and are reliable enough to explain the total variable.

The total variance extracted from the value explained by $57,447 \%$ should be $57,447 \%$ of the variation of the component variables (of the factors) explained by the observed variables (indicators). 


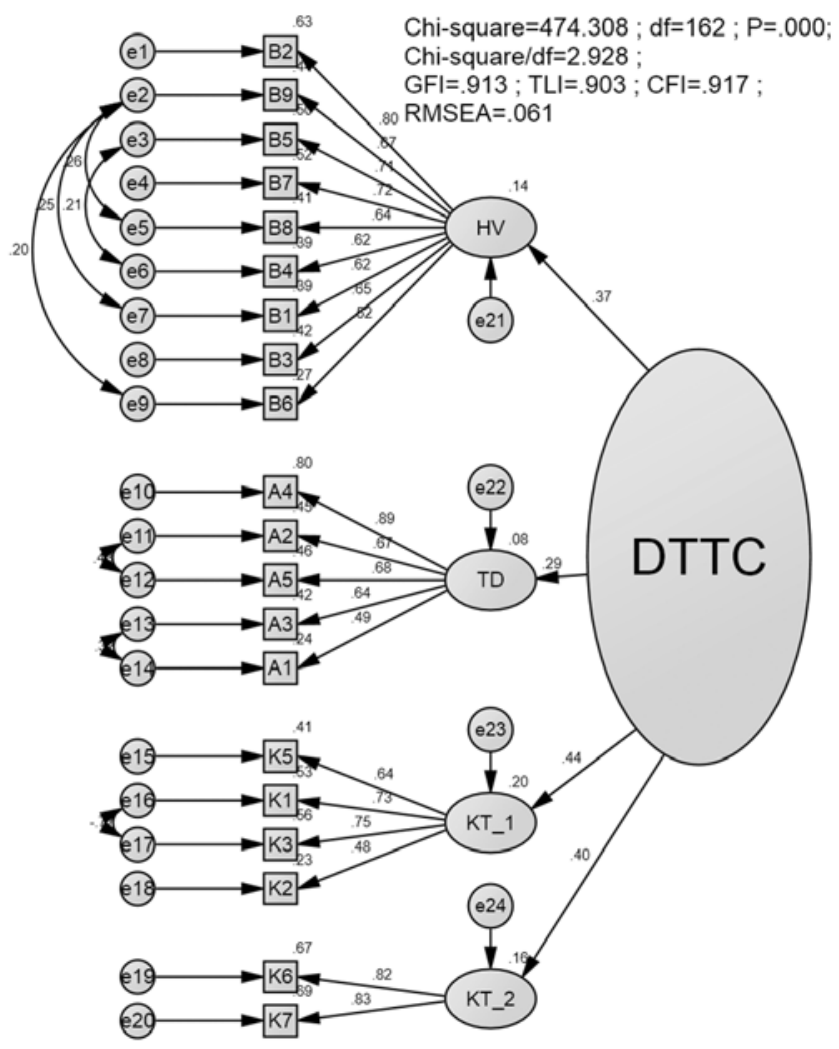

Figure 2. Results of CFA analysis

Source: Authors' development

Reliability: factors have satisfactory confidence factor $(\mathrm{CR}>0.5)$. The coefficients $\mathrm{CR}>$ 0.8 show the co-direction of observed variables in a very high factor.

Convergent validity: The Average Variance Extracted (AVE) ranged from $42.2 \%$ to $69.1 \%$, indicating the change of observed variables explains more than $42 \%$ of the variation of latent variables. Although less than 0.5 , these values are still acceptable (Hair et al, 2009).

Discriminant validity: When analyzing the above 6 factors, the MSV values were smaller than the AVE value, indicating the observed variable values are discriminant.

The results of the model are shown in Figure 2. The results of confirmatory factor analysis model show that the model is suitable (CMIN / DF $<3$, GFI, TLI, CFI $>0.9$ and RMSEA $<0.08 \ldots)$. The results are the elements of Financial Knowledge, Financial Attitude, and Financial Behavior reflecting an individual's financial performance in rural Vietnam. The higher the financial knowledge is, attitude and financial behavior is, the higher the financial literacy score and conversely is. 


\section{The Impact of Factors on Financial Literacy}

Table 2. Regression analysis of factors affecting the financial literacy of individuals

\begin{tabular}{lcccccc}
\hline $\begin{array}{l}\text { Independent } \\
\text { variables }\end{array}$ & $\begin{array}{c}\text { Adjusted } \\
\text { R-Square }\end{array}$ & F-statistic & Sig.(F-statistic) & $\begin{array}{l}\text { Standardized } \\
\text { Beta }\end{array}$ & t. & Sig. \\
\hline Gender & .320 & 60.980 & .000 & .020 & .537 & .591 \\
\hline Age & & & & .515 & 13.874 & .000 \\
\hline Education & & & & .118 & 3.138 & .001 \\
\hline Income & & & & .099 & 2.647 & .008 \\
\hline
\end{tabular}

Dependent variable: financial literacy

The adjusted $\mathrm{R}$ square is 0.320 , which means the model can explain $32 \%$ of the change of the dependent variable. The relatively large F-statistic value $(60,980)$ along with a very small p-value show that at least one of the independent variables has a significant effect on the dependent variable. To further examine the impact of these factors on financial literacy, the authors used Structural Equation Modeling (SEM).

The standardized coefficients of independent variables show that the level of income impact on financial literacy is 0.053 , the largest of all determinants. The level of influence of

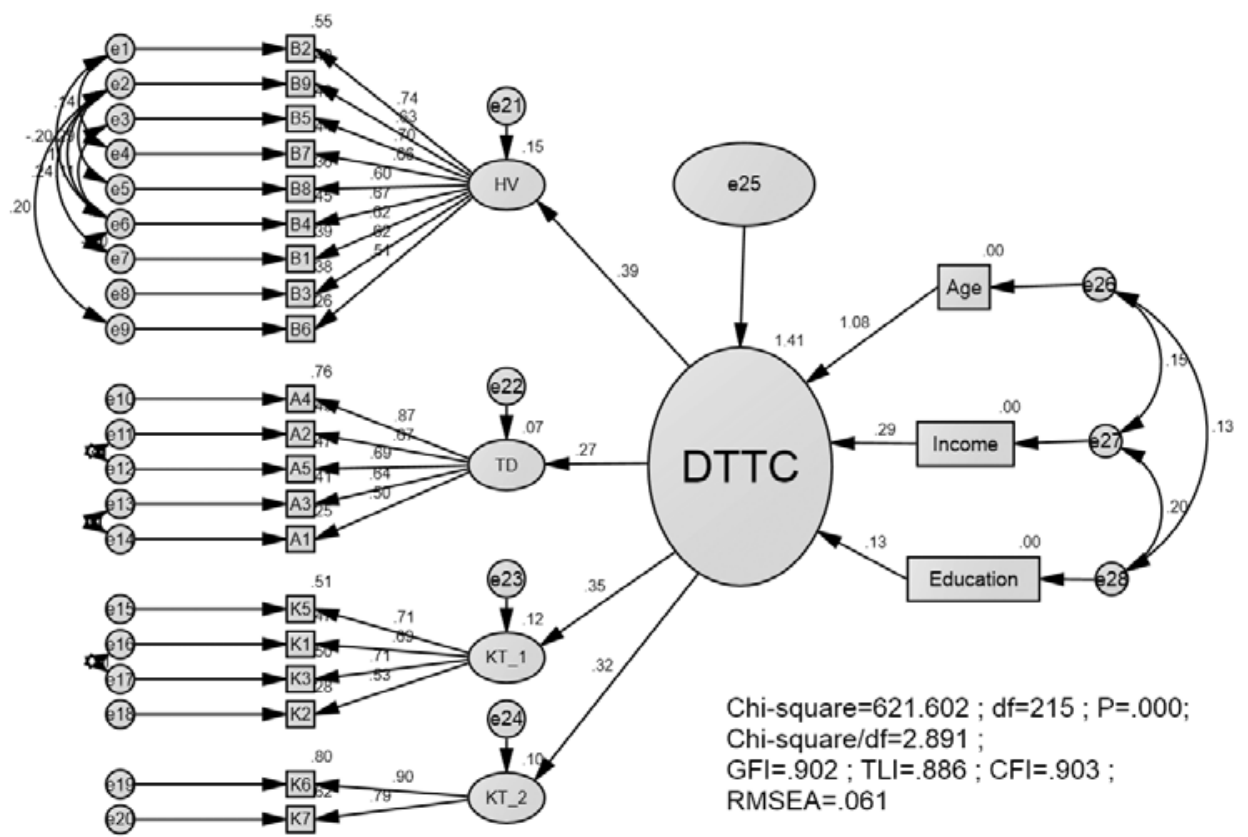

Figure 3: Structural Equation Modeling (SEM)

Source: Authors' development 
education and age is 0.026 and 0.025 respectively. The criteria for measuring the suitability of the model show that the value of Chi-square / $\mathrm{df}=2.891<3, \mathrm{GFI}=0.902, \mathrm{CFI}=0.903$ are greater than 0.9 , TLI is within an acceptable threshold, the coefficient RMSEA $=0.061$ $<0.08$, so the model achieves market data conformance. The results of the P-value values of the independent variables are all lower than the value of 0.05 , so the independent variables show influence on the dependent variable is financial literacy.

\section{Discussion and Policy Implications}

\section{Discussion}

\section{Determinants Influencing Financial Literacy}

\section{Education}

Education is a determinant influencing financial literacy. This result is the same with Brown et al. (2013); Lusardi (2013). On the other hand, the researches of Lusardi \& Tufano (2009) and Atkinson \& Messy (2012) have concluded that the elderly often have low level of financial literacy. In rural areas in Vietnam, the higher the level of education is, the higher the financial literacy score is.

\section{Income}

Financial literacy score of an individual is increased as the income is higher, which is similar to the conclusions in the study of Lusardi \& Tufano (2009). Although the difference is not significant, the uptrend of financial literacy can be easily recognised. Explaining this result, high-income people often have more experience not only in spending, savings, and investment but also on indicators and financial operations and good financial attitudes.

\section{Age}

The result shows that the higher the age is, the higher score of financial literacy is; this is similar to the conclusion of Lusardi \& Mitchell (2007). Explaining this hypothesis, rural people tend to make financial decisions according to previous experience. Therefore, older people often have a lot of experience in financial knowledge and financial attitudes.

\section{Reflective Factors}

Financial Knowledge

Results from the model has shown that the correlation coefficients of two groups, KT1 and KT2, to financial literacy are 0.44 and 0.40 and Sig $=0.000<0.05$. This means two groups of financial knowledge factors in particular or $\mathrm{H} 1$ hypothesis is accepted. This is also the result of Collins \& O'Rourke's studies (2010); Huston's (2010); Nicolini's et al. (2013), and 
Scheresberg's (2013). Thus, in rural Vietnam, financial knowledge is one of the positive factors reflecting financial literacy. When a person has good financial knowledge, he or she will have better investing and saving skills.

Financial Attitude

Positive financial attitude leads to higher level of financial literacy. Specifically, if the subject accurately and positively evaluates changes in the economy, or investment and savings, that person will be more accurate and positive. This point of view is also supported by Le (2015), Nguyen \& Le (2016). Therefore, improving financial attitudes through different methods can help people to increase financial literacy.

Financial Behaviour

The results has shown that financial behaviour positively reflects financial literacy; for that reason, $\mathrm{H} 3$ hypothesis is accepted. This is also the result achieved by Hilgert et al. (2003), Moore (2003), Atkinson \& Messy (2012), OECD (2013), Taft et al. (2013), Kaufman (2017). Specifically, if the person who has good investment, savings, exact spending; the ability to understand and the attitude of that person to the economy in general will be more accurate and positive. Therefore, it is necessary to develop a good investment and saving portfolio.

\section{Policy Implications}

In the present, financial literacy is still new in Vietnam and a specific implementation programme to improve financial literacy for the people has not yet been developed, especially for the people in rural areas in Vietnam, so it is still difficult to orientate. Based on what has been mentioned above, the authors identify advanced solutions of improving financial literacy in rural areas of Vietnam: focus on building the concept of financial literacy for individuals, families and communities, proposing for organizations involved in research, development and implementation of policies.

The designed financial literacy enhancement programmes need to be flexible and can be adjusted at any time when the environment changes or reflects the progress of the financial literacy development programmes. These programmes should focus through curriculum and news channels, television programmes about investment and savings planning, financial knowledge and financial attitudes. Politicians should also promote the power of visual and audio media directly through banners and radio systems, with brief and understandable messages and further expand communication channels about finance.

The government should have policies to encourage, especially towards those with low income and education level to consolidate and improve financial literacy in order to create a premise to improve living standards and economy development for the local. 


\section{References}

Agarwal, S., Driscoll, J.C., Gabaix, X., Laibson, D. (2008). Learning in the Credit Card Market. NBER Working Paper, No. 13822.

Agarwal, S., Driscoll, J., Gabaix, X., Laibson, D. (2009). The age of reason: financial decisions over the lifecycle with implications for regulation. Brookings Papers on Economic Activity, No. 2, pp. 51-117.

Alessie, R., Lusardi, A., van Rooij, M. (2008). Financial Literacy, Retirement Planning, and Household Wealth. NBER Working Paper, No. 15350.

Atkinson, A., Messy, F. (2012). Measuring Financial Literacy: Results of the OECD/ International Network on Financial Education (INFE) Pilot Study. OECD Working Papers on Finance, Insurance and Private Pensions, No. 15. OECD Publishing.

Avard, S., Manton, E., English, D., Walker, J. (2005). The financial knowledge of college freshmen. College Student Journal, vol. 39, No. 2, pp. 321-339.

Banks, J., Oldfield, Z. (2007). Understanding Pensions: Cognitive Function, Numerical Ability and Retirement Saving. Journal compilation ( Institute for Fiscal Studies.

Bhushan, P., Medury, Y. (2013). Financial Literacy and its Determinants. International Journal of Engineering, Business and Enterprise Applications, vol. 4, No. 2, pp. 155-160.

Braunstein, S.F., Welch, C. (2002). „Financial literacy: an overview of practice, research, and policy”, Federal Reserve Bulletin. Board of Governors of the Federal Reserve System (U.S.), November, pp. 445-457.

Bucher-Koenen, T., Ziegelmeyer, M. (2011). Who lost the most? Financial literacy, cognitive abilities and the financial crisis. MEA Discussion Paper, pp. 234-11.

Chen, H., Volpe, R.P. (1998). An analysis of personal financial literacy among college students. Financial Services Review, vol. 7, No. 2, p. 22.

Chowa, G., Despard, M., Osei-Akoto, I. (2012). Financial knowledge and attitudes of youth in Ghana. YouthSave Research Brief.

Chung, N., van Hinh, L. (2016). Financial literacy and banking system development sustainabilitypolicy suggestions for Vietnam. Posted in National Science workshop "Improving institutions for the sustainable development of Vietnam's banking system in the period 2016-2020", held by National Economics University and the Economic Committee of the Congress, November 2016.

Collins, J.M. (2012). Financial advice: A substitute for financial literacy? Financial Services Review, No. 21, pp. 307-322.

Dat, T.T. et.al. (2017). Vietnam economy 2016 - Annual economic report of National Economics University. Hanoi: NEU Press.

de Clercq, B., Venter, J.M.P. (2009). Factors influencing a prospective chartered accountant's level of financial literacy: an exploratory study. Meditari Accountancy Research, vol. 17, No. 2, pp. 47-60.

Fishbein, A. (1975). Belief, attitude, intention and behaviour: An introduction to theory and research.

Fisher, T., Hostland, D. (2002). The Long View: Labour Productivity, Labour Income and Living Standards in Canada. In The Review of Economic Performance and Social Progress.

Friedman. (2015). Providing and funding financial literacy programs for low-income adults and youth. The Finance Project.

Godwin, D.D. (1994). Antecedents and consequences of. Financial Counseling and Planning, No. 5.

Godwin, D.D., Carroll, D.D. (1986). Financial management attitudes and behaviour of husbands and wives. 
Godwin, D.D., Koonce, J.C. (1992). Cash flow management of low-income newlyweds. Financial Counseling and Planning, No. 3, pp. 17-42.

Grigion Potrich, A.C., Vieira, K.M., Mendes-Da-Silva, W. (2015). Development of a financial literacy model for university students.

Grohmann, A., Klühs, T., Menkhoff, L. (2017). Does Financial Literacy Improve Financial Inclusion? DIW Berlin Discussion Papers.

Hilgert, M., Hogarth, J., Beverly, S. (2003). Household financial management: the connection between knowledge and behavior. Federal Reserve Bulletin, pp. 309-322.

Hoa, N.T. (2009). Improving the poverty reduction policy of Vietnam to the year 2015. $\mathrm{PhD}$ thesis in economics, National Economics University, Hanoi.

Hogarth, J.M., Hilgert, M.A. (2002). Financial Knowledge, Experience and Learning Preferences: Preliminary Results from a New Survey on Financial Literacy. Consumer Interest Annual.

Holzmann, R. (2010). Bringing Financial Literacy and Education to Low and Middle Income Countries: The Need to Review, Adjust, and Extend Current Wisdom, World Bank, IZA and CES. Hung, A.A., Parker, A.M., Yoong, J. (2009). Defining and measuring financial literacy. [Working Paper No. 708], Social Science Research Network, Santa Monica.

Hung, N.V. (2015). Evaluation of financial literacy in VietNam and national financial education program. Asian Development Bank Institute, High-Level Global Symposium: Promoting Better Lifetime Planning through Financial Education, January 22-23 $3^{\text {th }}, 2015$.

Huston, S. (2010). Measuring financial literacy. The Journal of Consumer Affairs, vol. 44, No. 2, pp. 296-316.

Kaufman, R. (2007). Financial Attitude and Financial Literacy.

Klapper, L., Demirguc-Kunt, A., Singer, D., van Oudheusden, P. (2015). Measuring Financial Inclusion around the World.

Lucas, R.E. (1988). On the Mechanics of Economic Development. Journal of Monetary Economics, No. 22, pp. 3-42.

Lusardi, A. (2008). Financial Literacy: An Essential Tool for Informed Consumer Choice?

Lusardi, A., Bumcrot, C.B., Lin, J. (2013). The Geography of Financial Literacy. Scholar Commons.

Lusardi, A., Mitchel, O.S. (2011). Financial Literacy and Planning: Implications for Retirement Wellbeing. In Financial Literacy: Implications for Retirement Security and the Financial Marketplace. Eds. O.S. Mitchell and A. Lusardi. Oxford: Oxford University Press, pp. 17-39.

Lusardi, A., Mitchell, O.S. (2007). Financial Literacy and Retirement Preparedness: Evidence and Implications for Financial Education. p. 54.

Lusardi, A., Mitchell, O.S. (2011). Financial Literacy around the World: An Overview. Journal of Pension Economics and Finance, vol. 10, No. 4, pp. 497-508.

Lusardi, A., Mitchell, O.S. (2009). How Ordinary Consumers Make Complex Economic Decisions: Financial Literacy and Retirement Readiness. NBER Working.

Lusardi, A., Mitchell, O.S. (2011). The Outlook for Financial Literacy. In Financial Literacy: Implications for Retirement Security and the Financial Marketplace. Oxford: Oxford University Press, pp. 1-15. Lusardi, A., Michaud, P.C., Mitchell, O.S. (2011). Optimal Financial Literacy and Saving for Retirement. Wharton School Pension Research Council Working Paper, No. WP2011-20.

Lusardi, A., Michaud, P.C., Mitchell, O.S. (2013). Optimal Financial Literacy and Wealth Inequality. NBER Working Paper, No. 18669.

Lusardi, A., Schneider, D.J., Tufano, P. (2011). Financially Fragile Households: Evidence and Implications. Brookings Papers on Economic Activity, Spring, pp. 83-134. 
Lusardi, A., Tufano, P. (2009). Debt Literacy, Financial Experiences, and Overindebtedness. NBER Working Paper, No. 14808.

Marszałek-Kawa, J. (Ed.). (2012). Is the $21^{\text {st }}$ Century the Age of Asia? Deliberations on Economy. Torun: Adam Marszałek Publishing House, pp. 178.

Mason, C.L.J., Wilson, R.M.S. (2000). Conceptualising financial literacy. Occasional Paper.

Moore, D.L. (2003). Survey of Financial Literacy in Washington State: Knowledge, behavior, Attitudes, and Experiences.

Muske, G., Winter, M. (2001). In-depth look at family cash-flow management practices. Journal of Family and Economic Issues, vol. 22, No. 4, pp. 353-372.

Nanziri, E.L.; Leibbrandt, M. (2018). Measuring and profiling financial literacy in South Africa.

Nicolini, G., Cude, B.J., Chatterjee, S. (2013). Financial literacy: A comparative study across four countries. International Journal of Consumer Studies, No. 37, pp. 689-705.

Noctor, M., Stoney, S., Stradling, R. (1992). Financial Literacy, National Foundation for Educational Research, Slough.

OECD. (2013). Improving Financial Education Effectiveness through Behavioural Economics: OECD Key Findings and Way Forward.

OECD. (2018). OECD/INFE Toolkit for Measuring Financial Literacy and Financial Inclusion.

Porto, N., Xiao, J.J. (2016). Financial Literacy Overconfidence and Financial Advice Seeking. Journal of Financial Service Professionals, vol. 70, No. 4, pp. 78-88.

Robb, C.A., Babiarz, P., Woodyard, A. (2012). The demand for financial professionals' advice: the role of financial knowledge, satisfaction, and confidence. Financial Services Review, vol. 21, No. 4, pp. 291-305.

Robb, C.A., James, R.N. (2007). Personal financial knowledge among college students: Associations between individual characteristics and scores on an experimental measure of financial knowledge. Consumer Interests Annual, No. 54, p. 144.

Robb, C.A., Sharpe, D.L. (2009). Effect of personal financial knowledge on college students' credit card behavior, Journal of Financial Counseling and Planning, vol. 20, No. 1, pp. 25-43.

Robb, C.A., Woodyard, A. (2011). Financial Knowledge and Best Practice Behavior. Journal of Financial Counseling and Planning.

Schagen, S. and Lines, A. (1996). Financial Literacy in Adult Life: A Report to the Natwest Group Charitable Trust. NFER, pp. 36-45.

Scheresberg, C.D. (2013). Financial Literacy and Financial Behavior among Young Adults: Evidence and Implications.

Sekar, M., Gowri, M. (2015). A study on financial literacy and its determinants among generation $Y$ employees in Coimbatore city. Great Lakes Herald, vol. 9, No. 1, pp. 35-45.

Stango, V., Zinman, J. (2006). Fuzzy Math and Red Ink: Payment/Interest Bias, Intertemporal Choices, and Wealth Accumulation.

Taft, M., Hosein, Z., Mehrizi, S. (2013). The Relation between Financial Literacy. Financial Wellbeing and Financial Concerns.

Tezel, Z. (2015). Financial Education for Children and Youth. In Handbook of Research on Behavioral Finance and Investment Strategies: Decision Making in the Financial Industry, p. 24.

van Anh, T.T. (2017). Personal finance training to improve access to finance: the international experience and some lessons for Vietnam. Banking review, No. 14, pp. 51-57.

Vitt, L., Anderson, C., Kent, J., Lyter, D., Siegenthaler, J., Ward, J. (2000). Personal Finance and the Rush to 
Competence: Financial Literacy Education in the U.S. Middleburg.VA: Institute for Socio-Financial Studies.

WB (World Bank). (2015). Diagnostic review of consumer protection and financial literacy: volume 1 . WB. (2013). Financial Capacity Surveys around the world: why financial capacity is important and how surveys can help. Washington DC. WB. (2015). Diagnostic review of consumer protection and financial literacy: volume 1 - Vietnam. Financial and markets global practice.

Xiao, J.J., O'Neill, B., Proschaska, J.M., Kerbel, C.M., Brennan, P., Bristow, B.J. (2004). A consumer education programme based on the transtheoretical model of change. International Journal of Consumer Studies, vol. 28, No. 1, pp. 55-65.

Zhan, M. (2006). Assets, Parental Expectations and Involvement, and Children's Educational Performance. Children and Youth Services Review, vol. 28, No. 8, pp. 961-975.

\section{Authors}

\section{Phung Thanh Quang}

PhD, pt_quang@neu.edu.vn - National Economics University, Hanoi, Vietnam

Khuc The Anh, MA, anhkt@neu.edu.vn - National Economics University, Hanoi, Vietnam 